the Niemen; and at Wilna, the station following, where, on December 13th, six months after, Napoleon united his retreating force, reduced to less than 25,000 men, - the Russians, desertions and the cold disposing of the remainder.

After describing the terrible passage of the Beresina, Labaume, one of Napoleon's staff, writes:-"Arrived at the opposite bank, like ghosts returned from the infernal regions, we fearfully looked behind us, and beheld with horror the savage countries where we had suffered so much."

\title{
INOTICFS OF IMFMIOIRS.
}

Sketch of the Gkology and Palfontology of the Pliochne Beds of the Antwerp Distriot. By E. Vanden Brokck. Fasc. II. (Brussels, 1878.)'

TTHE first fascicule of this work was published in 1876 and noticed 1 in the Geological Magazine for July, 1877. With the fascicule now issued, it forms a stratigraphical introduction to MM. Vanden Broeck and Miller's Foraminifera of the Belgian Pliocene, being Part I. of that work.

The first fascicule dealt with the Lower Sands of Antwerp, the second takes up the Middle and Upper Sands of the same district, concluding with a general résumé of the entire work, a table of stratigraphical equivalence, here reproduced, a list of works on the subject, further data and corrections, and a topographical chapter explanatory of the map (not geological) of the area under discussion.

The Middle Sands have been designated as follows :

$$
\begin{array}{lccccc}
\text { Scaldesian (in part) } & \ldots & \ldots & \ldots & \ldots & \text { Dumont, } 1849 . \\
\text { Grey or Middle Crag } & \ldots & \ldots & \ldots & \ldots & \text { Lyell, 1852. } \\
\text { Grey Sands (in part) } & \ldots & \ldots & \ldots & \ldots & \text { Nyst, 1861. } \\
\text { Isocurdia cor Sands and Bryozoan } & \text { Rock } & \ldots & \ldots & \text { Cogels, 1874. }
\end{array}
$$

They consist generally of fine sand, more or less clayey, and very rarely coarse or pebbly: the glanconite grains in them are less abundant and smaller than in the Lower Sands. They have been divided into Grey and Yellow Sands, and correlated with the White and Red Crags of England respectively on the strength of this difference in colour. The fallacy of applying such a test is abundantly shown by the author, whose remarks on this important subject may be summed up as follows:-

Percolating water charged with carbonic acid and oxygen acts on both glauconite and carbonate of lime. Where percolation is rapid, it oxidises the glauconite; where slow, it dissolves away the fossils. Thus the surface of any glauconitic or shelly deposit. whether exposed directly or covered by permeable beds, is deprived of fossils and oxidised to a greater or less extent, the capricions

1 Les Foraminifères des Couches Pliocènes de la Belgique. Par E. Vanden Broeck et H. Miller. Ire partie: Esquisse Géologique et Paléontologique des Dépôts Pliocènes des Fnvirons d'Anvers. Par Ernest Vanden Broeck. Extrait des Annales de la Société Malacologique de Belgique, tome ix. pp. 83-379 [both fascicules], pl. iv. 
percolation of water giving rise to great irregularity of alteration, and producing the appearance, often strongly marked, of unconformity. To separate such deposits by their colour, therefore, is to mass all altered beds as of one age, all unaltered as of another, leading of course to hopeless confusion in lists of fossils based on this division, and this confusion has been increased by the inclusion of specimens from post-Tertiary deposits of similar lithological character. All lists hitherto published are therefore to a large extent worthless, with the exception of those recently compiled by M. Cogels.

The Middle Sands are rather Diestian than Scaldesian in their faunal affinities, and slightly anterior to the Coralline Crag, to which they are closely allied. By the northward and westward movement of the area of deposition, due to the elevation of Belgium and simultaneous depression of Holland and East Anglia, the Coralline Crag was still in process of deposition when the Belgian area emerged.

The Middle Sands have two facies, one of comparatively shallow water, distinguished by the predominance of Isocardia cor, the other of deeper water, notable for its profusion of Bryozoa. Enormous quantities of Cetacean bones, often as entire skeletons and connected vertebral columns, occur throughout the series, but the Ziphioids and Delphinidæ of the Lower Sands are here replaced by Mysticeti and Phocidæ. The fish are mostly Selachians, some of them of enormous bulk. ${ }^{1}$

Like the Coralline Crag, the Middle Sands have suffered great denudation previous to the deposition of the Upper Sands (=Red Crag).

Remarks on the horizon of certain local deposits and of Terebratula grandis (a Middle Sands species referred by M. Cogels, from deficient evidence, to the Lower Sands) are followed by a sketch of the geography of the Middle Sand period. The Belgian basin extended from Cotentin to Denmark and Iceland: the Mediterranean had nearly its present outline, whilst in Austria and South Russia occur isolated marine deposits of this age.

Passing to the Upper Sands we find a number of synonyms of which but one need be named, Sables a Trophon antiquum, given by M. Cogels in 1874.

The Upper Sands are of littoral origin, coarse and pebbly, rarely more than 14 feet thick, grey where protected by overlying impermeable beds from percolating water, but mostly oxidised. Their derived fossils being clearly distinguishable from contemporaneous species, these Antwerp beds may help to settle the vexed question of "derivation" in the English Red Crag, as many species from the latter, supposed to be derived, are found in the Upper Sands.

As with the previous series, the Upper Sands are slightly anterior to the Red Crag, except perhaps the Crag of Walton-on-the-Naze, which has an earlier facies than the rest of the Red Crag, and may be synchronous with the Upper Sands. The base of both contains

1 Carcharodon megalodon was 70 feet long, and its jaws were 14 feet in circum. ference. 
Synoptraat and Chronological Table of the Pliocenr and Quaternary Brps OF THE ANTWERT BASIN.

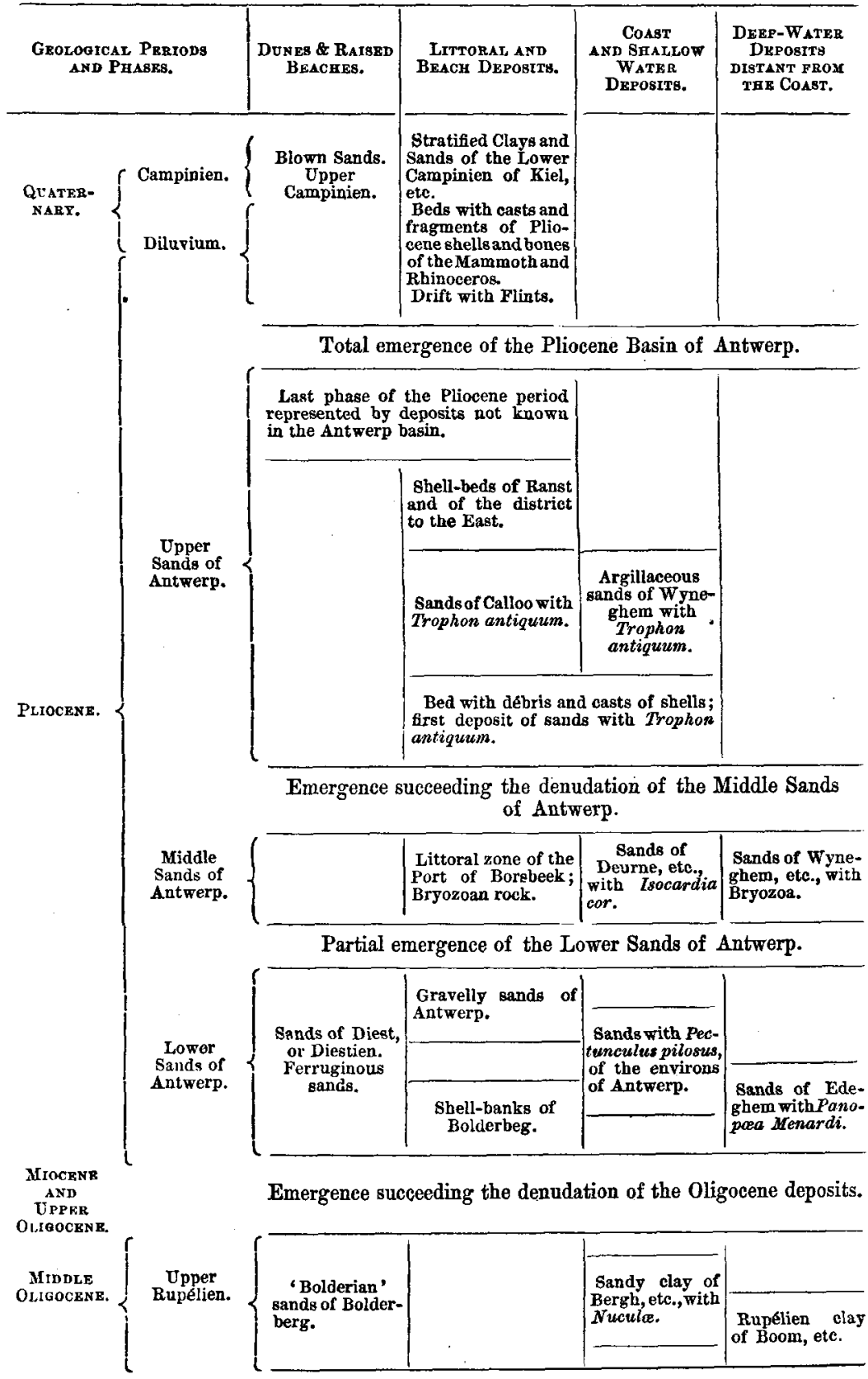


rolled and water-worn bones, many of them belonging to Cetaceans that could not have lived in the shallow seas of the period: these remains have been derived mostly, if not entirely, from the Middlo Sands, where they abound in the unrolled and connected state.

Littoral beds occur East of Antwerp, indicating a later advance of the sea, possibly that produced by the depression which in Suffolk introduced the Chillesford series.

The geography of the Upper Sands period resembled in the main that of the preceding epoch, with the addition of a wide sheet of fresh or brackish water, which stretched from Austria to Tartary, and left as its isolated relics the Black, Caspian, and Aral seas.

[Copious lists of fossils, with statistical analyses of each, are adduced by the author in proof of his views, but for these the reader is referred to the original. The author desires the writer of this notice to add that he will be happy to present a copy of the work to any one interested in the subject. Applications may be made to W. Whitaker, Esq., B.A., F.G.S., Museum, Jermyn Street, S.W.]

W. H. D.

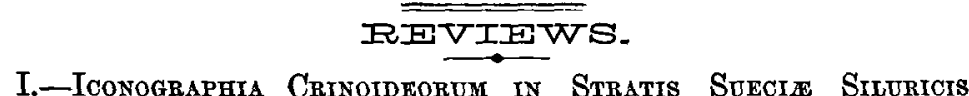

Fossilium Auotore N. P. Angezin. Opus Postumum Edendum Curater Regia academia Solmatiarum Sugcica. Folio, pp. 64. Cum Tabulis XXIX. (Holmiæ, Samson \& Wallin; London, Trübner \& Co., 1878.)

THERE is probably no better proof of disinterested regard which 1 can be displayed for a deceased scientific man, than that his friends should undertake the very difficult and laborious task of preparing his posthumous works for publication. It was this feeling which led the disciples of the illustrious Cuvier to publish "Le Règne Animal," and Charles Murchison to edit "Falconer's Palæontological Memoirs." A noble example of this self-denying spirit is shown in the work before us by Prof. S. Lovén, and Dr. G. Lindström, the former a colleague of Angelin's, and the latter his recently appointed successor at Stockholm.

The unpublished MSS. of Angelin, handed over to the Academy by his family, were found to consist of various memoirs on the 'Irilobites, Cephalopoda, Graptolites, etc., but for the most part incomplete and unarranged.

In 1851 he published under the title of "Palæontologia Suecica" the first part of his Monograph of the Silurian Crustacea of Scandinavia; the second part entitled "Palæontologia Scandinavica" appeared in 1854. At his death in February, 1876, all the beautiful plates, 29 in number, published in the present volume, were found ready prepared and lithographed, part of the text was printed and part was found in MS. The Editors modestly lay claim only to the plan and systematic arrangement of the work (except the Cystidea), they having giren Angelin's own generic and specific characters, merely reducing the same to order, and adding some needful notes on the synonymy. The name of Prof. S. Lovén, 